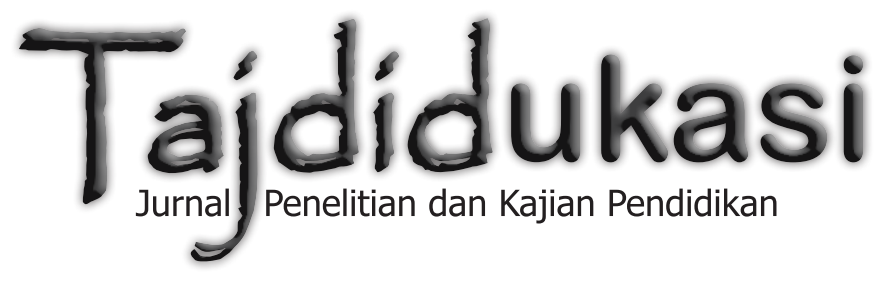




\section{Tajdidukasi}

Volume VIII, No. 1, Januari 2018

ISSN: 1979-6943

Tajdidukasi: Jurnal Penelitian dan Kajian Pendidikan merupakan jurnal Penelitian dan Kajian Pendidikan yang berisi Penelitian Tindakan Kelas (PTK) dan Penelitian Tindakan Sekolah (PTS) serta Kajian Pendidikan interdisipliner di Perguruan Tinggi yang diterbitkan Majelis Pendidikan Dasar dan Menengah Pimpinan Wilayah Muhammadiyah Daerah Istimewa Yogyakarta. Artikel hasil PTK dan PTS serta kajian pemikiran pendidikan ditulis oleh para Guru dan Kepala Sekolah serta Dosen dalam mengujicobakan metode dan strategi pembelajaran untuk meningkatkan kualitas pendidikan baik SD/MI, SMP/MTs dan SMA/MA/SMK serta Perguruan Tinggi. Artikel PTK dan PTS fokus pada mata pelajaran di sekolah/madrasah, seperti Ilmu Pengetahuan Alam (IPA), Imu Pengetahuan Sosial (IPS), Matematika, Fisika, Kimia, bahkan teknik, seperti Teknik Mesin, Elektro, Informatika dan lain sebagainya. Sementara itu, artikel Kajian Pendidikan merupakan penelitian interdisipliner dan multidisipliner yang dilakukan Dosen di Perguruan Tinggi terhadap khasanah keIslaman.

Tajdidukasi: Jurnal Penelitian dan Kajian Pendidikan adalah jurnal terbuka yang versi softfile-nya bisa dibaca dan diakses secara gratis, sementara versi print out/ hardcopy dapat diperoleh dengan menghubungi distributor di alamat serial tajdidukasi.ac.id. Sof-file keseluruhan artikel yang diterbitkan dapat diakses melalui Tajdidukasi Open Access Juornal di www.dikdasmenpwmdiy.or.id

\section{Pimpinan Editor \\ Suyadi, Universitas Ahmad Dahlan (UAD) Yogyakarta, Indonesia}

\section{Anggota Editor}

Arif Budi Raharjo, Universitas Muhammadiyah Yogyakarta (UMY), Indonesia

Achmad Muhammad, UIN Sunan Kalijaga Yogyakarta, Indonesia

Hendro Widodo, Universitas Ahmad Dahlan (UAD) Yogyakarta

Mundzirin Yusuf, UIN Sunan Kalijaga Yogyakarta, Indonesia

Sumedi, UIN Sunan Kalijaga Yogyakarta, Indonesia

Sukamto, Universitas Muhammadiyah Yogyakarta (UMY), Indonesia

Sumarsono, UIN Sunan Kalijaga Yogyakarta Indonesia

Sarjilah (Lembaga Penjaminan Mutu Pendidikan) Yogyakarta

Fathur Rahman, M.Si., Universitas Negeri Yogyakarta (UNY) Indonesia

\section{Editor Pelaksana}

Suryanto, Universitas Muhammadiyah Yogyakarta (UMY), Indonesia

Suyatno, Universitas Ahmad Dahlan (UAD) Yogyakarta

Farid Setiawan, Universitas Ahmad Dahlan (UAD) Yogyakarta

Alamat Redaksi:

Kantor Majelis Pendidikan Dasar dan Menengah Pimpinan

Wilayah Muhammadiyah D.I. Yogyakarta

Jl. Gedongkuning No. 130B Yogyakarta

Kode Pos : 55171

Telephone : (0274) 377078

Facsimile : (0274) 371718

Website : www.dikdasmenpwmdiy.or.id

E-Mail : tajdidukasi@dikdasmenpwmdiy.or.id 


\title{
PENINGKATAN MINAT BELAJAR FISIKA MELALUI PEMBELAJARAN BERBASIS MULTIPLE INTELLIGENCE BAGI PESERTA DIDIK SMK
}

\author{
Tanti Kurniah Sari \\ SMK Muhammadiyah Wonosari \\ tantiksari@gmail.com
}

\begin{abstract}
Abstrak
Peserta didik SMK Muhammadiyah Wonosari memiliki minat belajar fisika yang tergolong rendah. Hal ini disebabkan oleh anggapan siswa sendiri yang memandang fisika hanya berisi rumus yang sulit dipahami dan membosankan. Penelitian ini bertujuan untuk meningkatkan minat belajar fisika melalui pembelajaran berbasis Multiple Intelligence pada peserta didik. Penelitian ini merupakan Penelitian Tindakan Kelas (PTK) dengan model Kemmis McTaggart yang terdiri dari 4 tahap yaitu perencanaan, pelaksanaan, observasi dan refleksi. Proses pembelajaran fisika disesuaikan dengan 8 kecerdasan menurut Gardner. Hasil penelitian ini menunjukkan bahwa pada tahap pratindakan $62 \%$ peserta didik kurang berminat, karena pembelajaran fisika hanya mengedepankan kecerdasan matematika-logika. Pada siklus I minat peserta didik meningkat $20 \%$ ketika pembelajaran fisika menggunakan 8 jenis kecerdasan, sehingga bisa diikuti lebih banyak peserta didik. Pada siklus II minat belajar peserta didik meningkat 38\% ketika pembelajaran lebih megendepankan kecerdasan naturalis sehingga $96 \%$ peserta didik berminat belajar fisika.
\end{abstract}

Kata Kunci: Minat, Belajar Fisika, dan Multiple Intelligence

\section{A. PENDAhuluan}

Berdasarkan Struktur Kurikulum Pendidikan Menengah Kejuruan Tahun 2017, fisika merupakan salah satu mata pelajaran dasar bidang keahlian pada Kompetensi Keahlian Multimedia. Dijadikannya fisika sebagai mata pelajaran dasar bidang keahlian, menuntut peserta didik dapat menguasai seluruh kompetensi yang telah ditentukan. Hal ini dikarenakan, penguasaan kompetensi fisika berpengaruh penting terhadap pemahaman peserta didik pada mata pelajaran kejuruan.
Kenyataannya, minat belajar fisika peserta didik kelas X Multimedia di SMK Muhammadiyah Wonosari masih tergolong rendah seperti Tabel 1.berikut.

Tabel 1. Minat Belajar Peserta Didik Awal

\begin{tabular}{|l|c|c|}
\hline Jumlah Peserta didik & Kategori & $\begin{array}{c}\text { Persentase } \\
(\%)\end{array}$ \\
\hline Sangat Baik & 0 & 0 \\
\hline Baik & 9 & 38 \\
\hline Kurang baik & 15 & 62 \\
\hline Total & 24 & 100 \\
\hline
\end{tabular}


Berdasarkan Tabel 1. di atas, hanya 9 peserta didik yang memiliki minat baik dan 15 peserta didik belum memiliki minat belajar fisika yang baik.

Menurut Djamarah (2011: 166) minat adalah kecenderungan yang menetap untuk memperhatikan dan mengenang beberapa aktivitas. Seseorang yang berminat terhadap suatu aktivitas akan memperhatikan aktivitas itu secara konsisten dengan rasa senang. Hal ini dipertegas oleh pendapat Slameto (2003: 180) bahwa minat adalah rasa lebih suka dan rasa ketertarikan pada suatu hal, tanpa ada yang perintah atau paksaan dari luar. Seseorang yang menaruh minat pada suatu bidang tertentu akan lebih mudah mempelajari bidang tersebut. Sejalan dengan pendapat Syah (2010: 133) bahwa minat adalah kecenderungan dan kegairahan yang tinggi atau keinginan yang besar terhadap sesuatu. Adanya minat dan kemauan sangat mempengaruhi corak perbuatan yang akan diperlihatkan oleh seseorang. Jika seseorang tidak memiliki minat, kemauan, atau kehendak maka ia tidak akan bisa mengikuti proses belajar dengan baik. Peserta didik yang menaruh minat pada mata pelajaran tertentu akan lebih mudah mempelajarinya, karena adanya perasaan senang dan penuh perhatian. Beberapa indikator peserta didik memiliki minat terhadap suatu kegiatan tertentu menurut Slameto (2003: 180), yaitu : 1) Minat selalu diikuti dengan perasaan senang; 2) Rasa lebih suka dan rasa keterikatan pada suatu hal atau aktivitas daripada yang lainnya;
3) Dimanifestasikan melalui partisipasi dalam suatu aktivitas; dan 4) Memberikan perhatian yang lebih besar terhadap subjek tersebut.

Minat mempunyai peran penting dalam proses pembelajaran. Kegiatan belajar-mengajar akan menjadi efektif apabila muncul minat dalam diri peserta didik. Menurut James dalam Usman (2006: 27) minat merupakan faktor utama yang menentukan derajat keaktifan belajar peserta didik. Minat dapat mempengaruhi kualitas pencapaian hasil belajar peserta didik dalam bidang studi tertentu. Artinya, jika peserta didik menaruh minat pada mata pelajaran tertentu, maka ia akan memusatkan perhatiannya pada pelajaran tersebut daripada yang lain. Karena perhatian yang intensif itu, memungkinkan peserta didik lebih giat belajar sehingga akhirnya mencapai prestasi yang diharapkan. Hal tersebut dipertegas oleh Slameto (2010: 57) bahwa minat memiliki pengaruh besar terhadap hasil belajar, apabila peserta didik tidak berminat pada suatu materi pelajaran, maka peserta didik tidak dapat belajar dengan sebaik-baiknya.

Kurangnya minat belajar fisika pada peserta didik kelas X Multimedia terhadap materi pelajaran menjadi penyebab rendahnya hasil belajar peserta didik. Hasil belajar merupakan hasil dari suatu interaksi tindak belajar dan tindak mengajar ( Dimyati \& Mudjiono, 2006: 3-4). Hal ini bersesuaian dengan hasil penelitian Nurhasanah, S. \& Sobandi, A (2016: 6) bahwa, minat belajar berpengaruh posi- 
tif dan signifikan terhadap hasil belajar. Adanya peningkatan minat belajar, akan diikuti dengan peningkatan hasil belajar.

Minimnya minat belajar fisika peserta didik kelas X Multimedia, disebabkan oleh anggapan bahwa fisika adalah mata pelajaran yang memuat banyak rumus dan sulit diaplikasikan pada soal. Keadaan tersebut berimbas pada hasil belajar peserta didik. Terbukti pada hasil belajar fisika peserta didik kelas X Multimedia tergolong rendah dengan capaian rata-rata 6,7. Rata-rata tersebut berada di bawah Kriteria Ketuntasan Minimum (KKM) yang ditetapkan sekolah yaitu 7,5. Dari 24 peserta didik, terdapat 7 peserta didik yang telah mencapai KKM sedangkan 17 lainnya masih berada di bawah KKM sehingga persetase kelulusan yang diperoleh hanya sebesar 29\%. Menurut Mundilarto (2010: 14) pada hakikatnya fisika adalah ilmu dasar yang terdiri atas fakta, konsep, prinsip, hukum, postulat, dan teori. Fisika merupakan ilmu yang terbentuk melalui prosedur baku yang disebut sebagai metode ilmiah. Dengan demikian, seharusnya pembelajaran fisika tidak hanya sekedar berhitung dengan rumus-rumus yang ada.

Proses pembelajaran yang cenderung selalu berhitung secara tidak langsung mendorong bentuk evaluasi hasil yang dibuat lebih dominan melalui perhitungan matematis. Keadaan tersebut sangat merugikan peserta didik yang lemah dalam kecerdasan/kemampuan berhitung. Ada peserta didik yang unggul dalam kemampuan berhitung namun lemah dalam bahasa, ada peserta didik yang unggul dalam kemampuan bahasa namun lemah dalam kemampuan praktek. Tidak semua peserta didik unggul dalam seluruh kecerdasan.

Pada dasarnya, setiap peserta didik memiliki kemampuan masing-masing dan tidak semua kemampuan hanya diukur dengan kemampuan dalam berhitung angka. Menurut Gardner (Chatib, 2011: 68) kecerdasan seseorang dapat dilihat dari banyak dimensi, tidak hanya kecerdasan verbal (bahasa) atau kecerdasan matematis, akan tetapi kecerdasan itu "multiple" (jamak atau majemuk). Kecerdasan anak terdiri dari delapan kecerdasan yaitu, linguistik, matematika logika, visual-spasial, naturalis, musikal, interpersonal, intrapersonal dan kinestetik yang disebut sebagai Multiple Intelligence. Tidak semua peserta didik unggul pada seluruh aspek kecerdasan. Oleh karena itu, kedelapan kecerdasan tersebut perlu diakomodir dalam proses pembelajaran melalui model yang tepat sehingga seluruh peserta didik memiliki minat belajar fisika yang baik dan akan berimbas pada pencapaian hasil belajar. Teori kecerdasan majemuk merupakan validasi gagasan bahwa perbedaan yang berada pada diri anak adalah penting. Pemakaiannya dalam pendidikan sangat tergantung pada pengenalan, pengakuan, penghargaan terhadap berbagai cara peserta didik belajar dan minat masingmasing anak (Jasmin, J., 2007: 13). Menurut Teori Multiple Intelligence, peserta didik akan lebih mudah memahami pelajaran jika materinya disajikan sesuai dengan inteligensi yang menonjol dalam diri peserta didik. Karena itu, 
teori ini perlu diterapkan dalam rangka mempermudah pencapaian tujuan pendidikan. (Hamzah, A. 2009: 11).

Menurut Ula (2013: 146-151) ada beberapa strategi yang dapat digunakan dalam implementasi Multiple Intelligence dalam pembelajaran diantaranya : 1)Pada kecerdasan linguistik, peserta didik diberikan ruang yang lebih untuk belajar kolaboratif, debat dan diskusi; 2) Kecerdasan matematis-logis, peserta didik diberikan kesempatan untuk mengasah kemampuan menghitung; 3) Kecerdasan visual-spasial, peserta didik diberikan pembelajaran yang berkaitan denga media, gambar dan alat bantu visual spasial; 4) Kecerdasan kinestetik, peserta didik diberikan kesempatan untuk melakukan kegiatan fisik seperti percobaan; 5) Kecerdasan musikal, peserta didik dilibatkan dalam pembelajaran yang berkaitan dengan musik; 6) Kecerdasan interpersonal, peserta didik lebih didorong untuk bekerjasama dengan yang lainnya; 7) Kecerdasan intrapersonal, peserta didik diberikan ruang untuk melakukan refleksi dan berpikir mandiri; dan 8) Kecerdasan naturalistik, peserta didik lebih diberikan pembelajaran yang secara langsung berhubungan dengan kehidupan sehari-hari. Dengan menerapakan Multiple Intelligence dalam pembelajaran, peserta didik dihadapkan pada kenyataan bahwa teori yang diterima secara nyata ditemui di dalam kehidupan sehari-hari dan dapat dialami sendiri. Selain itu proses pendidikan dapat mengakomodir setiap kebutuhan peserta didik dan sesuai dengan keunikannya masingmasing. (Amir, 2013: 14).
Berdasarkan uraian masalah di atas, penelitian ini bertujuan untuk meningkatkan minat belajar fisika melalui pembelajaran berbasis Multiple Intelligence pada peserta didik kelas X SMK Muhammadiyah Wonosari.

\section{B. METODE PENELITIAN}

Penelitian ini merupakan pencermatan dalam bentuk tindakan terhadap kegiatan belajar yang sengaja dimunculkan dan terjadi dalam sebuah kelas secara bersamaan yang disebut dengan Penelitian Tindakan Kelas (PTK) (Suyadi: 2012). Model yang digunakan adalah model Kemmis \& Mc Taggart. Penelitian ini dilaksanakan di SMK Muhammadiyah Wonosari pada Semester Genap Tahun 2018. Subjek pada penelitian ini adalah peserta didik dengan kompetensi keahlian Multimedia yang berjumlah 24 anak. PTK model Kemmis \& Mc Taggart adalah seperti gambar berikut.

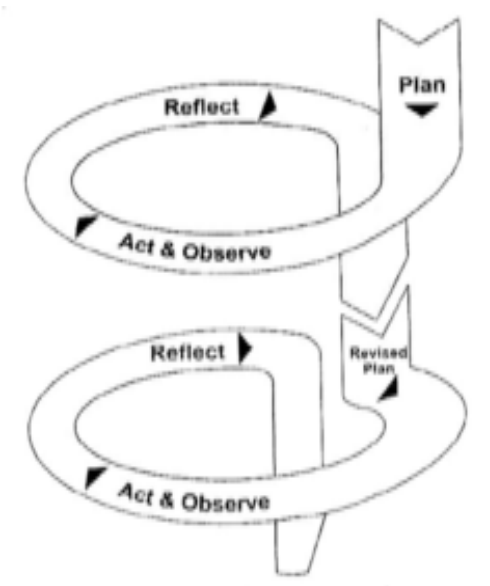

Gambar 1. PTK Model Kemmis \& McTaggart (Uno, H.B. 2011: 69) 
Pada tahap Pratindakan, kegiatan yang dilakukan terdiri dari: 1) Identifikasi kesulitan-kesulitan yang dialami peserta didik, skor awal minat belajar fisika dan pemahaman awal peserta didik terhadap pembelajaran fisika yang akan diterapkan; 2) Menentukan waktu pelaksanaan penelitian. Pada tahap Siklus I, kegiatan yang dilakukan: 1) Pembuatan RPP, lembar keterlaksanaan RPP, soal tes pemahaman dan angket minat peserta didik; 2) Pelaksanaan pembelajaran fisika berbasis Multiple Intelligence; 3) Observasi proses pembelajaran untuk mengetahui minat belajar peserta didik; dan 4) Mengumpulkan dan menganalisis data yang diperoleh selama observasi. Pada Siklus II kegiatan yang dilakukan berdasarkan hasil refleksi pada siklus I diantaranya: 1) Pembuatan RPP, lembar keterlaksanaan RPP, soal tes pemahaman dan angket minat peserta didik ; 2) Pelaksanaan pembelajaran fisika berbasis Multiple Intelligence; 3) Observasi proses pembelajaran untuk mengetahui minat belajar peserta didik; dan 4) Mengumpulkan dan menganalisis data yang diperoleh selama observasi.

\section{HASIL DAN PEMBAHASAN}

\section{Deskripsi Kondisi Awal}

Sebelum melakukan penelitian, dilakukan kegiatan pratindakan. Kegiatan ini bertujuan untuk mengidentifikasi kesulitan-kesulitan yang dialami peserta didik dan mengetahui skor awal minat belajar fisika serta mempersiapkan pem- belajaran berbasis Multiple Intelligence. Menurut Suparno (2008: 79-97) terdapat empat langkah yang perlu diperhatikan dalam mempersiapkan pembelajaran berbasis Multiple Intelligence yaitu: 1) Pengenalan Multiple Intelligence pada peserta didik; 2) Mempersiapkan pembelajaran, 3) Menentukan strategi pembelajaran, dan 4) Menentukan evaluasi. Berdasarkan hasil pengamatan pada pembelajaran fisika sebelum siklus dimulai, sebagian besar waktu pelajaran digunakan guru untuk menjelaskan materi dan menuliskan persamaan di papan tulis. Beberapa peserta didik fokus mendengarkan penjelasan dari guru namun, lama-kelamaan peserta didik terlihat bosan bahkan mengantuk saat mengikuti pembelajaran. Hal itu terlihat dari perilaku peserta didik yang meletakkan kepalanya di meja dan menyangga dagunya dengan tangan. Ketika guru memantik semangat peserta didik dengan pertanyaan, beberapa peserta didik terlihat diam dan tidak berani menjawab pertanyaan guru. Di samping itu, beberapa peserta didik yang dari awal terlihat memperhatikan, ketika diberikan pertanyaan peserta didik tersebut tidak bisa menjawab. Berdasarkan ciri-ciri tersebut menunjukkan bahwa peserta didik minat belajar fisika tergolong rendah.

Pada tahap pratindakan dilakukan pengambilan skor minat belajar peserta didik sebagai dasar untuk mengetahui minat belajar fisika peserta didik. Adapun hasil angket minat belajar fisika pada tahap pratindakan dapat dilihat 
pada Tabel 2. berikut.

Tabel 2. Minat Belajar Fisika tahap Pratindakan

\begin{tabular}{|l|c|c|}
\hline Jumlah Peserta didik & Kategori & Persentase \\
\hline Sangat Baik & 0 & $0 \%$ \\
\hline Baik & 9 & $38 \%$ \\
\hline Kurang baik & 15 & $62 \%$ \\
\hline Tidak baik & 0 & $0 \%$ \\
\hline \multicolumn{1}{|c|}{ Total } & $\mathbf{2 4}$ & $\mathbf{1 0 0 \%}$ \\
\hline
\end{tabular}

Dari tabel di atas, terdapat $38 \%$ peserta didik yang memiliki minat belajar baik dan $62 \%$ peserta didik yang memiliki minat belajar kurang baik. Hal tersebut menunjukkan bahwa minat belajar peserta didik masih jauh dari dari kriteria yang telah ditentukan yaitu minimal mendapat nilai $\geq 75 \%$ peserta didik minimal mencapai minat belajar dengan kategori baik (Pee, 242: 281).

Materi fisika yang digunakan pada penelitian ini disesuaikan dengan KIKD pada Permendikbud No. 33 Tahun 2017 yaitu Kompetensi Dasar (KD) 3.7 dan 3.7. KD 3.7 memuat aspek kognitif yaitu menganalisis gaya dan hubungan gaya, massa dan gerakan benda pada gerak lurus. KD 4.7 memuat aspek keterampilan yaitu melakukan percobaan terkait interaksi gaya serta hubungan gaya, massa dan percepatan dalam gerak lurus serta makna fisiknya.

\section{Deskripsi Siklus I}

\section{a. Perencanaan Kegiatan}

Perencanaan pembelajaran dilaksanakan pada Hari Rabu, 3 Januari 2018 dengan melakukan kegiatan persiapan mengajar diantaranya:

1) Penentuan Pokok Bahasan Materi

Pada siklus I materi yang digunakan adalah percobaan sederhana mengenai Hukum I Newton, Hukum II Newton dan Hukum III Newton.

2) Penyusunan Rencana Pelaksanaan

Pembelajaran

RPP yang disusun berisi tentang pokok bahasan yang telah disepakati sebelumnya dan disesuaikan dengan strategi pembelajaran berbasis $\mathrm{Mul}$ tiple Intelligence. RPP ini digunakan sebagai pedoman dalam pelaksanaan pembelajaran.

3) Penyusunan Lembar Kerja Peserta

Didik dan Evaluasi

Lembar Kerja Peserta Didik (LKPD) di susun dengan memuat kedelapan aspek kecerdasan yaitu verbal, linguistik, matematika, visual-spasial, naturalis, interpersonal, intrapersonal dan musikal. LKPD ini akan mendorong peserta didik untuk mengasah kedelapan kecerdasan yang dimiliki, selain itu, dengan adanya LKPD ini dapat digunakan untuk menganalisis kecerdasan peserta didik pada masingmasing aspek.

4) Persiapan Media Pembelajaran

Pada tahap ini, seluruh media pembelajaran yang diperlukan disiapkan seperti laptop dan LCD.

\section{b. Pelaksanaan Kegiatan}

Pelaksanaan tindakan ini dilakukan dengan pedoman RPP yang telah dibuat. Tindakan pada siklus I dilaksa- 
nakan dalam dua kali pertemuan yaitu 10 dan 17 Januari 2018. Pada pertemuan pertama dilaksanakan pada hari Rabu 10 Januari 2018 pukul 10.00 - 11.35 WIB dan pertemuan kedua dilaksanakan pada hari Rabu 17 Januari 2018 pukul 10.00-11.35 WIB. Kegiatan yang dilakukan pada siklus I diantaranya:

1) Percobaan Sederhana mengenai Hukum I, II dan III Newton

Kegiatan percobaan ini dilakukan secara berkelompok. Pada percobaan Hukum Newton aspek kecerdasan yang diterapkan adalah kinestetik, interpersonal dan visual-spasial. Kecerdasan kinestetik ini dinilai pada keterampilan peserta didik dalam melakukan percobaan sesuai dengan lembar kerja yang telah disediakan. Kecerdasan interpersonal dinilai berdasarkan kemampuan kerjasama peserta didik dalam kelompok, sedangkan kecerdasan visual-spasial dinilai berdasarkan kemampuannya mengamati dan menelaah selama proses percobaan berlangsung.

2) Diskusi Kelompok

Pada kegiatan ini kecerdasan yang digunakan adalah interpersonal dengan berdikusi, kecerdasan visual spasial dengan melakukan literasi bersama dari berbagai sumber, dan kecerdasan linguistik dalam menyampaikan hasil diskusi.

\section{c. Observasi}

Observasi dilakukan bersamaan dengan pemberian tindakan. Proses pembelajaran yang dilakukan secara keseluruhan telah sesuai dengan RPP yang dibuat. Pada saat pemberian apersepsi, beberapa peserta didik terlihat antusias menduga keadaan penumpang saat bus tiba-tiba direm. Secara bersautan peserta didik mencoba menanggapi pernyataan guru. Saat kegiatan percobaan berlangsung, sebagian besar peserta didik berpartisipasi aktif untuk melakukan percobaan di dalam keompoknya. Satu dengan yang lainnya saling membantu untuk melaksanakan dan mengamati kegiatan yang dilakukan, namun ada dua peserta didik yang terlihat kurang tertarik untuk ikut berpartisipasi aktif dalam kegiatan percobaan tersebut. Kegiatan presentasi dilakukan pada pertemuan kedua. Saat perwakilan kelompok menyampaikan hasil diskusinya kelompok lain terlihat menyimak apa yang dipresentasikan dengan seksama. Saat diberikan kesempatan untuk memberikan tanggapannya beberapa peserta didik berani memberikan komentar dan sanggahannya.

\section{d. Refleksi}

Refleksi dilakukan pada akhir siklus untuk melakukan evaluasi terkait pelaksanaan siklus I.

1. Evaluasi Proses

a) Kegiatan percobaan secara berkelompok yang menerapkan kecerdasan kinestetik, interpersonal dan visual-spasial mampu menumbuhkan perasaan senang dan ketertarikan beberapa peserta didik terhadap kegiatan pembelajaran fisika. Tiga jenis percobaan sederhana yang dilakukan secara langsung membutuhkan waktu 
yang cukup lama sehingga perlu diefisienkan kembali. Pada saat kegiatan pembelajaran terdapat dua peserta didik yang kurang antusias untuk melakukan kegiatan percobaan secara berkelompok, mereka cenderung pasif saat kegiatan berlangsung.

b) Kegiatan diskusi mampu memunculkan partisipasi aktif beberapa peserta didik untuk berpendapat mengenai kegiatan percobaan yang telah dilakukan.

c) Kegiatan presentasi memunculkan perhatian peserta didik untuk mengetahui hasil diskusi kelompok lain. Namun ada juga beberapa peserta didik yang terlihat tidak tertarik untuk mendengarkan hasil diskusi kelompok lain dan cenderung untuk bercerita dengan teman yang lain.

2. Evaluasi hasil

Evaluasi hasil ini terdiri dari dua hal yaitu hasil minat belajar dan hasil belajar peserta didik. Hasil belajar ini digunakan untuk mendukung penelitian bahwa perubahan minat belajar peserta didik berpengaruh terhadap hasil belajarnya. Hasil minat belajar peserta didik dapat dilihat pada Tabel 3 berikut.

Tabel 3 . Hasil Skala Minat Belajar Fisika Siklus I

\begin{tabular}{|l|l|l|}
\hline \multicolumn{1}{|c|}{ Kategori } & $\begin{array}{l}\text { Jumlah Peser- } \\
\text { ta didik }\end{array}$ & Persentase \\
\hline Sangat baik & 3 & $12 \%$ \\
\hline Baik & 11 & $46 \%$ \\
\hline Kurang baik & 10 & $42 \%$ \\
\hline Tidak baik & 0 & $0 \%$ \\
\hline Total & 24 & $100 \%$ \\
\hline
\end{tabular}

Peserta didik dikatakan memiliki minat belajar fisika apabila minimal telah mencapai kategori baik. Berdasarkan data di atas, peserta didik yang memiliki minat belajar fisika 58\% atau 14 anak. Jumlah ini telah meningkat dari tahap pratindakan yang hanya mencapai $38 \%$.

Minat belajar fisika peserta didik tersebut ditinjau dari perasaan senang, ketertarikan siswa, perhatian siswa, dan keterlibatan siswa dalam mengikuti pembelajaran fisika. Peningkatan pada masing-masing indicator tersebut secara nyata berimbas pada peningkatan minat belajar fisika. Hal tersebut diperkuat oleh hasil penelitian Rusmiati (2017: 11) tentang Pengaruh Minat Belajar terhadap Prestasi Belajar Bidang Studi Ekonomi Siswa MA Al Fattah Sumbermulyo bahwa, perasaan senang saat mengikuti pelajaran, ketertarikan peserta didik pada proses pembelajaran yang sedang berlangsung, perhatian peserta didik terhadap kegiatan pembelajaran dan keterlibatan atau keaktifan siswa pada setiap tahap pembelajaran yang terjadi merupakan indicator peningkatan minat belajar peserta didik.

Penelitian serupa yang menerapkan pembelajaran berbasis Multiple Intelligence adalah Susanta, S.F. (2015: 84) bahwa penerapan pembelajaran berbasis Multiple Intelligence antara lain siswa lebih senang dan bersemangat dalam mengikuti pembelajaran. Siswa lebih senang menunjukkan bahwa pembelajaran tersebut mendukung peningkatan minat belajar pada indikator perasaan 
senang. Siswa lebih bersemangat merupakan bentuk keterkatikan siswa terhadap pembelajaran yang termasuk ke dalam salah satu indikator peningkatan minat belajar. Kondisi tersebut berpengaruh terhadap prestasi belajar siswa yang ditunjukkan dengan peningkatan nilai ulangan harian.

\section{Deskripsi Siklus II}

Siklus II merupakan tindak lanjut dari siklus I. Tujuan dari adanya siklus II yaitu untuk memenuhi kriteria keberhasilan yaitu peserta didik mendapatkan persentase $\geq 75 \%$ peserta didik mencapai minat belajar minimal kategori baik. Sama seperti siklus I, tahap dari siklus ini meliputi perencanaan, pelaksanaan tindakan, pengamatan dan refleksi. Adapun rincian hasil pada masing-masing tahap sebagai berikut:

\section{a. Perencanaan Kegiatan}

Perencanaan pembelajaran meliputi kegiatan persiapan pembelajaran yang berisi hal-hal yang perlu dan harus dilakukan sebelum melaksanakan kegiatan pembelajaran. Persiapan dilakukan pada tanggal 21 Januari 2018. Persiapan tersebut meliputi:

1) Penentuan Pokok Bahasan Materi

Pada siklus II aplikasi Hukum Newton dan Jenis-jenis Gaya dan penerapan persamaan Hukum Newton.

2) Penyusunan Rencana Pelaksanaan Pembelajaran

RPP yang disusun berisi tentang pokok bahasan yang telah disepakati sebelumnya dan disesuaikan dengan strategi pembelajran berbasis Multiple Intelligence. RPP ini digunakan sebagai pedoman dalam pelaksanaan pembelajaran.

3) Penyusunan Lembar Kerja Peserta Didik Dan Evaluasi

4) Persiapan Media Pembelajaran

b. Pelaksanaan Kegiatan

Tindakan pada siklus II dilaksanakan dalam dua kali pertemuan yaitu 24 dan 31 Januari 2018. Pada pertemuan pertama dilaksanakan pada hari Rabu 24 Januari 2018 pukul 10.00 - 11.35 WIB dan pertemuan kedua dilaksanakan pada hari Rabu 31 Januari 2018 pukul 10.00-11.35 WIB. Pada pertemuan pertama dilaksanakan pada hari Rabu 24 Januari 2018 pukul 10.00 - 11.35 WIB.

Kegiatan yang dilakukan pada siklus I diantaranya:

1) Aplikasi dari Hukum Newton

Pada kegiatan pembelajaran ini aspek kecerdasan yang diterapkan adalah naturalis, linguistik, intrapersonal, dan matematika logika. Pada siklus II ini kegiatan pembelajaran dilakukan secara individu. Tahap pertama kecerdasan yang diterapkan adalah kecerdasan naturalis, linguistik dan intrapersonal di asah melalui kegiatan menulis cerita. Seluruh peserta didik diminta untuk menggali ingatannya mengenai peristiwa sehari-hari yang berkaitan dengan Hukum Newton yang telah dipelajari pada siklus I. Setelah selesai menuliskan cerita peserta didik menuliskan konsep Hukum Newton yang terdapat pada 
peristiwa sehari-hari. Melalui kegiatan tersebut peserta didik dapat memahami konsep Hukum Newton dalam kehidupan sehari-hari. Kecerdasan musikal diterapkan melalui kegiatan mendengarkan lagu tentang Hukum Newton yang merupakan aransemen dari lagu menghapus jejakmu milik peterpan. Setelah mendengarkan, peserta didik diminta menuangkan kreativitasnya untuk menciptakan lagu yang liriknya berisi materi Hukum Newton. Secara sukarela peserta didik diminta maju ke depan untuk menyampaikan tulisan maupun lagu yang telah dibuatnya. Dari kegiatan di atas peserta didik lebih memahami konsep dari Hukum Newton.

Tahap kedua, guru menggambarkan katrol dan bidang miring di papan tulis dan peserta didik diminta untuk mengamatinya. Guru menjelaskan mengenai gaya-gaya yang bekerja pada gambar di papan tulis serta memberikan analisis matematisnya. Selanjutnya peserta didik diminta untuk mengerjakan soal yang ada pada LKPD. Pada proses pengerjaan soal, peserta didik berdiskusi dengan teman yang lainnya. Kegiatan pembelajaran ditutup dengan salam.

2) Pengerjaan LKPD III secara Berpasangan

Pada pembelajaran ini aspek kecerdasan yang diterapkan adalah kecerdasan interpersonal, matematika logika, linguistik, dan visual-spasial. Kecerdasan interpersonal diasah melalui proses kegiatan yang dilakukan secara berkelompok. Peserta didik diberikan sebuah aragraph rumpang kemudian diminta untuk melengkapi dengan kata yang tepat. Kegiatan ini bertujuan untuk mengasah kecerdasan linguistiknya. Selain itu, peserta didik juga diberikan teka teki silang kemudian diminta untuk mencari jawaban sesuai pertanyaan yang telah disediakan dengan membuat garis horizontal maupun vertical. Kegiatan ini bertujuan untuk mengasah kecerdasan visual spasial peserta didik. Setelah selesai, dilanjutkan dengan kegiatan analisis gambar. Pada kegiatan ini peserta didik diminta untuk menentukan jenis gaya yang bekerja pada system serta menentukan nilai percepatan, gaya dan perpindahan benda. Aspek yang ditekankan kegiatan ini adalah visual spasial dan matematika logika.

\section{c. Observasi}

Pengamatan dilakukan bersamaan dengan pemberian tindakan. Proses pembelajaran yang dilakukan secara keseluruhan telah sesuai dengan RPP yang dibuat. Kecerdasan yang diterapkan pada siklus pertama ini adalah kecerdasan interpersonal, matematika logika, visual-spasial, naturalis, linguistik dan musikal. Masing-masing aspek kecerdasan telah diterapkan pada kegiatan pembelajaran sesuai dengan yang telah direncanakan.

Pada pertemuan pertama, saat apersepsi, beberapa peserta didik terlihat antusias menjawab apa yang terjadi pada pesawat saat pra lepas landas dan mengapa orang harus menggunakan 
tenaga yang besar agar lemari bergerak. Secara bersautan peserta didik mencoba menanggapi pertanyaan guru. Pada saat peserta didik menuliskan cerita dalam kehidupan sehari-hari yang berkaitan dengan konsep Hukum Newton, beberapa dari mereka senang menuangkan memorinya dalam tulisan. Saat guru memutar lagu menghapus jejakmu yang telah diubah liriknya berhubungan dengan konsep Hukum Newton, seluruh peserta didik terlihat tertarik mendengarkan lagu dengan seksama. Sebagian dari mereka ikut bernyanyi seperti lagu yang didengarkan. Kemudian pada saat diminta untuk menuangkan kreativitasnya dalam mengarang lagu bertemakan Hukum Newton seluruh peserta didik aktif berkreasi. Ada yang sibuk menggali ingatan lagu-lagu yang disukai dengan mengubah kata-kata sendiri da nada pula yang memanfaatkan jejaring internet untuk menyusun kata yang tepat. Proses pembelajaran yang berlangsung dilalui peserta didik dengan senang. Kegiatan ini membuat peserta didik memahami lebih dalam mengenai Hukum Newton.

Pada pertemuan kedua, kegiatan pembelajaran dilakukan dengan cara diskusi berpasangan. Saat peserta didik diberikan paragraph rumpang, mereka saling berdiskusi untuk memilih kata yang tepat. Beberapa dari mereka juga mengajukan pertanyaan pada guru saat menemui hal kurang jelas. Selanjutnya pada saat pengisian TTS peserta didik sangat antusias untuk mencermati kata yang ada di dalamnya. Pada saat mela- kukan analisis gambar, beberapa peserta didik bertanya pada guru mengenai gaya yang harus dilukiskan.

d. Refleksi

Refleksi dilakukan pada akhir siklus untuk mengevaluasi pelaksanaan siklus II.

1) Evaluasi Proses

Secara keseluruhan, proses pembelajaran pada siklus II tidak menemui hambatan. Seluruh metode yang digunakan dalam pembelajaran dengan menerapkan Multiple Intelligence dapat memunculkan perasaan senang, ketertarikan, partisipasi aktif dan perhatian peserta didik selama pembelajaran berlangsung.

2) Evaluasi hasil

Hasil minat belajar peserta didik dapat dilihat pada Tabel 4 berikut.

Tabel 4. Hasil Skala Minat Belajar Fisika Siklus II

\begin{tabular}{|l|c|c|}
\hline Kategori & $\begin{array}{c}\text { Jumlah } \\
\text { Peserta didik }\end{array}$ & Persentase (\%) \\
\hline Sangat baik & 23 & 96 \\
\hline Baik & 1 & 4 \\
\hline Kurang baik & 0 & 0 \\
\hline Tidak baik & 0 & 0 \\
\hline Total & 24 & 100 \\
\hline
\end{tabular}

Berdasarkan data di atas, persentase ketuntasan peserta didik secara keseluruhan adalah 96\% dengan kata lain tindakan pada siklus II telah memenuhi kriteria ketuntasan yang telah ditetapkan.

Hasil ini bersesuaian dengan hasil penelitian Firdaus, H. K. (2017: 130) bahwa minat belajar peserta didik pada 
siklus II meningkat dari siklus I. Pada siklus I minat belajar siswa hanya mencapai $52,78 \%$ dan pada siklus II meningkat menjadi 94,44\%.

3. Peningkatan Minat Belajar melalui Pembelajaran Berbasis Multiple Intelligence

Indikator minat belajar peserta didik terdiri dari: 1) Perasaan senang, 2) Ketertarikanpada aktivitas pembelajaran, 3) Partisipasi aktif, dan 4) Perhatian yang besar terhadap aktivitas pembelajaran. Perolehan rata-rata nilai minat belajar fisika peserta didik dari tahap pratindakan, siklus I dan siklus II mengalami peningkatan seperti pada Gambar 2 berikut.

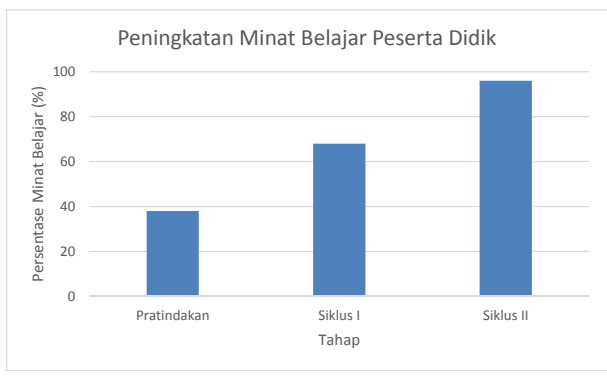

Gambar 2. Diagram Batang Peningkatan Minat Belajar Peserta Didik

Berdasakan diagram di atas, minat belajar peserta didik mengalami peningkatan yang signifikan dari tahap pratindakan hingga siklus II. Pada tahap pratindakan hanya $38 \%$ peserta didik yang memiliki minat belajar fisika yang baik. Setelah diberikan pembelajaran dengan menerapkan 8 kecerdasan menurut Gardner pada tahap Siklus I terdapat $68 \%$ peserta didik yang memiliki minat belajar fisika yang baik yang artinya minat belajar fisika meningkat $20 \%$ Pada siklus II diberikan pembelajaran dengan menerapkan 8 kecerdasan dengan mengedepankan kecerdasan naturalis mampu menaikkan minat belajar peserta didik dengan signifikan. Hampir seluruh peserta didik memiliki minat belajar yang baik yaitu $96 \%$ yang artinya meningkat $28 \%$.

Hasil ini bersesuaian dengan hasil penelitian Perdana, D.D., dkk (2014: 74) bahwa minat belajar peserta didik mengalami peningkatan dari siklus I $51,85 \%$ dan pada siklus II meningkat menjadi $77,78 \%$. Hal serupa juga diungkapkan pada hasil penelitian Sanubari, F., dkk (2014: 6) bahwa minat belajar peserta didik mengalami peningkatan dari siklus I 77,94\% dan pada siklus II $85,63 \%$.

Hasil belajar peserta didik pada tahap pratindakan, siklus I, dan siklus II juga dianalisis untuk mengetahui seberapa besar peningkatannya. Berdasarkan rata-rata hasil belajar peserta didik pada pratindakan hingga siklus II juga mengalami peningkatan seperti pada Gambar 3 berikut.

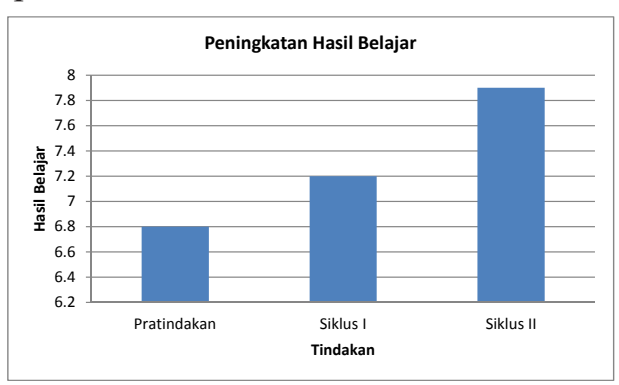

Gambar 3. Diagram Batang Peningkatan Hasil Belajar Peserta Didik 
Berdasakan diagram di atas, ratarata hasil belajar peserta didik mengalami peningkatan dari tahap pratindakan hingga siklus II. Pada tahap pratindakan hasil belajar peserta didik hanya mencapai nilai 6,8 , kemudian pada tahap Siklus I mencapai nilai 7,2 dan pada siklus II menjadi 7,9.

Menurut James dalam Usman (2006: 27) minat merupakan faktor utama yang menentukan derajat keaktifan belajar peserta didik. Minat dapat mempengaruhi kualitas pencapaian hasil belajar peserta didik dalam bidang studi tertentu. Hal tersebut dibuktikan dari hasil penelitian bahwa peningkatan minat belajar peserta didik berpengaruh terhadap pencapaian hasil belajar seperti pada Gambar 4. berikut.

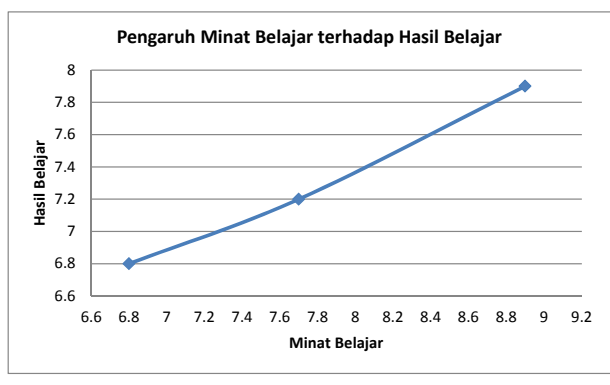

Gambar 4. Grafik Pengaruh Minat Belajat terhadap Hasil Belajar

Berdasarkan grafik diatas, terlihat bahwa peningkatan minat belajar peserta didik secara tidak langsung berpengaruh terhadap hasil belajar peserta didik. Hasil ini bersesuaian dengan hasil penelitian Nurhasanah, S. \& Sobandi, A (2016: 7) bahwa minat belajar memiliki pengaruh yang signifikan terhadap hasil belajar. Dengan demikian dapat disimpulkan bahwa hasil belajar siswa dapat ditingkatkan melalui peningkatan minat belajar peserta didik. Artinya semakin baik minat belajar siswa akan berdampak pada hasil belajar peserta didik yang semakin baik. Akan tetapi, hal ini bertolak belakang dengan hasil penelitian Sobari, F (2017: 6) bahwa bahwa minat belajar memiliki pengaruh yang cukup rendah terhadap hasil belajar dengan hasil 36,8\% dan 63,2\%. Perbedaan ini dikarenakan terdapat factor internal yang turut mempengaruhi minat belajar peserta didik seperti faktor kepribadian individual dan faktor ekstern seperti faktor dorongan orang tua, factor teman sebaya, faktor guru, faktor metode pembelajaran, faktor lingkungan dan perkembangan tekhnologi. Pengaruh minat belajar terhadap hasil belajar dipertegas dari hasil penelitian Solikhah, dkk (2015: 11) bahwa model pembelajaran Multiple Intelligence dapat meningkatkan hasil belajar peserta didik.

\section{KESIMPULAN}

Minat belajar fisika peserta didik dapat ditingkat melalui penerapan pembelajaran berbasis Multiple Intelligence. Multiple Intelligence atau kecerdasan majemuk terdiri atas kecerdasan kinestetik, linguistik, musikal, visual-spasial, naturalistik, matematika logika, intrapersonal dan interpersonal. Kedelapan kecerdasan tersebut, diintegrasikan dalam proses pembelajaran sehingga kegiatan pembelajaran menjadi lebih 
bervariasi dan mampu meningkatkan minat belajar peserta didik. Hasil penelitian ini menunjukkan bahwa Pada tahan pratindakan $62 \%$ peserta didik kurang berminat, karena pembelajaran fisika hanya mengedepankan kecerdasan matematika-logika. Pada siklus I minat peserta didik meningkat $20 \%$ ketika pembelajaran fisika menggunakan 8 jenis kecerdasan, sehingga bisa diikuti lebih banyak peserta didik. Pada siklus II minat belajar peserta didik meningkat 38\% ketika pembelajaran lebih megendepankan kecerdasan naturalis sehingga $96 \%$ peserta didik berminat belajar fisika.

\section{DAFTAR PUSTAKA}

Amir, A. (2013). Pembelajaran Matematika dengan Menggunakan Kecerdasan Majemuk (Multiple Intelligences), I(01), 1-14. Retrieved from http://jurnal.iain-padangsidimpuan.ac.id/index.php/LGR/ article/view/196/177

Chatib, M. (2010). Sekolahnya Manusia: Sekolah Berbasis Multiple Intelligences di Indonesia. Bandung: Kaifa

Dimyati \& Mudjiono. (2006) Belajar dan Pembelajaran. Jakarta: PT Rineka Cipta

Djamarah, S.B. (2011). Psikologi Belajar. Jakarta: PT Rineka Cipta

Firdaus, H.K. (2017) Penerapan Strategi Pembelajaran Multiple Intellingences dalam Meningkatkan Minat Belajar Peserta Didik pada Mata
Pelajaran Fiqh Kelas VIII Di MTS Darul Ulum Kaliasin Kecamatan Tanjung Bintang Kabupaten Lampung Selatan. UIN Raden Intan Lampung. Retrieved from http:// repository.radenintan.ac.id/1159/1/ Skripsi_Firdaus.pdf

Hamzah, A. (2009). Teori Multiple Intelligences dan Implikasinya terhadap Pengelolaan Pembelajaran. Tadris, 4(2), 1-11. Retrieved from http://ejournal.stainpamekasan.ac.id/index.php/tadris/article/ view/256/247

Jasmine, J. (2007). Panduan Praktis Mengajar Berbasis Kecerdasan Majemuk. Bandung: Nuansa

Keputusan Dirjen Pendidikan Dasar dan Menengah tentang Struktur Kurikulum Pendidikan Menengah Kejuruan Tahun 2017

Mundilarto.(2010). Penilaian Hasil Belajar Fisika. Yogyakarta: Pusat Pengembangan Instruktional Sains

Nurhasanah, S., \& Sobandi, A. (2016). Minat Belajar Sebagai Determinan Hasil Belajar Siswa. Jurnal Pendidikan Manajemen Perkantoran, 1(1), 135-142. Retrieved from http://ejournal.upi.edu/index.php/jpmanper/article/download/3264/2338

Pee S. et. al. (2002). Brestfeeding And Complementary Feending Practices In Indonesia Annual Report. Jakarta: Helen Keller Worldwide

Permendikbud No 330 Tahun 2017 ten- 
tang Standar Isi Pendidikan Dasar dan Menengah

Rusmiati. (2017). Pengaruh Minat Belajar terhadap Prestasi Belajar Bidang Studi Ekonomi Siswa Ma Al Fattah Sumbermulyo. UTILITY: Jurnal Ilmiah Pendidikan Dan Ekonomi, 1(1), 21-36.

Slameto. (2003). Belajar dan FaktorFaktor yang Mempengaruhinya. Jakarta: PT Rineka Cipta.

Sanubari, F. (2017). Pengaruh Minat Belajar terhadap Hasil Belajar Siswa pada Mata Pelajaran Ilmu Pengetahuan Sosial di SMP Negeri 1 Jonggo. UIN Syarif Hidayatullah

Solikhah, Maaratus dkk. (2015). Pengaruh Pembelajaran berbasis Multiple Intelligences terhadap Hasil Belajar Matematika Siswa Kelas III SDN Brayublandong Mojokerto, 4(2), 141-152. Retrieved from http://ojs.umsida.ac.id/index.php/ pedagogia/article/view/17/89

SK Dirjen Pendidikan Dasar dan Menengah No. 130/D/KEP/KR/2017 tentang Sktruktur Kurikulum Pendidikan Menengah Kejuruan
Suparno. (2008). Teori Integensi Ganda dan Aplikasinya di Sekolah: Cara Menerapkan Teori Multiple Intelegence Howard Garner. Yogyakarta: Kanisius

Susanta, S.F. (2016) Pembelajaran Berbasis Multiple Intelligences dan Dampaknya Terhadap Prestasi Belajar Pai Siswa Kelas III SD Islam Al Azhar 38 Bantul. UIN Sunan Kalijaga. Retrieved from http://digilib. uin-suka.ac.id/21674/2/11410103 BAB-I_IV-atau-V_DAFTAR-PUSTAKA.pdf

Suyadi. (2013). Panduan Guru Professional Penelitian Tindakan Kelas (PTK) dan Tindakan Sekolah (PTS). Yogyakarta: Andi Ofset

Syah, M. (2001). Psikologi Pendidikan dengan Pendekatan Baru. Bandung: PT Remaja Rosdakarya

Usman, A. (2006). Metodologi Penelitian Sosial. Jakarta : Bumi Aksara

Ula, S.S. (2013). Revolusi Belajar. Bandung: Ar-Ruzz Media

Uno, Hamzah B, dkk. (2011). Mengelola Kecerdasan Dalam Pembelajaran. Jakarta: Bumi Aksara 